WOODROW WILSON

AND THE WORLD OF TODAY 
It is by the widening of vision that nations, as men, grow and are made great. We need not fear the expanding scene. It was plain destiny that we should come to this, and if we have kept our ideals clear, unmarred, commanding through the great century and the moving scenes that made us a nation, we may keep them also through the century that shall see us a great power in the world. Let us put our leading characters at the front; let us pray that vision may come with power; let us ponder our duties like men of conscience and temper our ambitions like men who seek to serve, not to subdue, the world; let us lift our thoughts to the level of the great tasks that await us, and bring a great age in with the coming of our day of strength.

Woodrow WiLson, "The Ideals of America," Atlantic Monthly, XC (December, 1902), 


\title{
Woodrow Wilson \\ and The World of Today
}

\author{
Essays by \\ Arthur S. Link \\ William L. Langer \\ Eric F. Goldman
}

\author{
Edited by \\ Arthur P. Dudden
}

Philadelphia
UNIVERSITY OF PENNSYLVANIA PRESS 
(C) 1957 by the Trustees of the University of Pennsylvania

Published in Great Britain, India, and Pakistan

by the Oxford University Press

London, Bombay, and Karachi

Library of Congress Catalogue Card Number: $57-7219$

Manufactured in the United States of America by Book Craftsmen Associates, Inc., New York 